\title{
Chemical Investigation of Alkaleri Kaolin Deposit for Its Potential Industrial Applications
}

\author{
Zerendu Chikaodinaka Christian ${ }^{1, ~}$, Ameji John Philip ${ }^{1}$, Haruna Muhammad Idris², \\ Zaharaddeen Shehu ${ }^{3}$ \\ ${ }^{1}$ Department of Chemistry, Ahmadu Bello University, Zaria, Nigeria \\ ${ }^{2}$ Department of Chemistry, Audu Bako College of Agriculture, Dambatta, Kano, Nigeria \\ ${ }^{3}$ Department of Science Laboratory Technology, Jigawa State Polytechnic, Dutse, Nigeria
}

Email address:

chikaodinaka111@gmail.com (Z.C. Christian)

${ }^{*}$ Corresponding author

\section{To cite this article:}

Zerendu Chikaodinaka Christian, Ameji John Philip, Haruna Muhammad Idris, Zaharaddeen Shehu. Chemical Investigation of Alkaleri Kaolin Deposit for Its Potential Industrial Applications. American Journal of Chemical Engineering. Vol. 5, No. 6, 2017, pp. 130-134. doi: 10.11648/j.ajche.20170506.12

Received: September 11, 2017; Accepted: September 26, 2017; Published: November 11, 2017

\begin{abstract}
The kaolin sample from Alkaleri in Bauchi State was analyzed to ascertain its metal and metal oxides content and to investigate their potential use for industrial purposes. Neutron activation analysis technique was used for the metals while the turbimetric and Molybdenum Blue methods were used to determine the sulphates and phosphates respectively. The result showed that the Alkaleri kaolin with $\mathrm{Fe}\left(1.3 \times 10^{-3} \%\right), \mathrm{K}_{2} \mathrm{O}(0.53 \%), \mathrm{Na}_{2} \mathrm{O}(0.018 \%), \mathrm{TiO}_{2}\left(4.6 \times 10^{-4} \%\right)$, meets the specification for paper, ceramics, rubber, porcelain, pharmaceutics, cosmetics and glaze production but its alumina content is slightly below the minimum requirement for these uses except for rubber for which the content is within the specified value and for tiles for which the value is slightly above the specification. The combination of sulphate and phosphate contents which are $4.71 \%$ and $2.18 \mathrm{ppm}$ respectively could increase their absorbing property and makes them more useful for medicinal and cosmetic purposes. The $\mathrm{pH}$ value of the kaolin was found to be 4.3 which makes it unsuitable for most industrial purposes, e.g. rubber and plastic production, the $\mathrm{pH}$ need to be increased to 5-7 range (the preferred value for most industrial uses). The nitrate and chloride contents indicated values of $18 \mathrm{ppm}$ and $0.3 \mathrm{ppm}$ respectively.
\end{abstract}

Keywords: Alkaleri, Kaolin, Neutron Activation, Metals, Metal Oxide

\section{Introduction}

Kaolin, named after Kao-Ling, the location of its first major utilization in China, is a common phyllosilicate mineral of the formula $\mathrm{Al}_{2} \mathrm{Si}_{2} \mathrm{O}_{5} \mathrm{OH}_{4}$ [1]. Kaolin is composed of alternating layers of silicate $\left(\mathrm{Si}_{2} \mathrm{O}_{5}\right)$ and gibbsite $\left(\mathrm{Al}_{2}(\mathrm{OH})_{4}\right)[2,3]$ and its crystals are usually arranged in pseudohexagonal plates forming flaky aggregates with the same chemistry as its polymorphs halloysite, dickite and nacrite. Kaolin clay is formed as a result of the alteration of alumosilicates (feldspar, feldspathoid, spodumene, sillimanite) and volcanic glasses, sometimes altered by acidic hydrothermal solutions. Besides kaolinite, kaolin clay usually contains different minerals (such as quartz, feldspar, and calcite). It is mostly white, but it also can be grey, yellow or red [1].

Kaolin finds wide applications in the production of cement, ceramics, bricks and porcelain [4-8]. The greatest demand for kaolinite is in the paper industry to produce a high quality paper [9-11]. It is also used as filler for paint, rubber and plastics [4, 6, 7]. Kaolin clay found its application in medicine, in toothpaste, in cosmetics and as a food additive. Recently, a specially formulated spray is used in fruit and vegetable production to repel the insects and prevent sun burn [12].

Chemical analysis of Alkaleri kaolin has become necessary in order to ascertain its suitability for certain industrial applications. 


\section{Materials and Methodology}

\subsection{Sample Collection and Preparation}

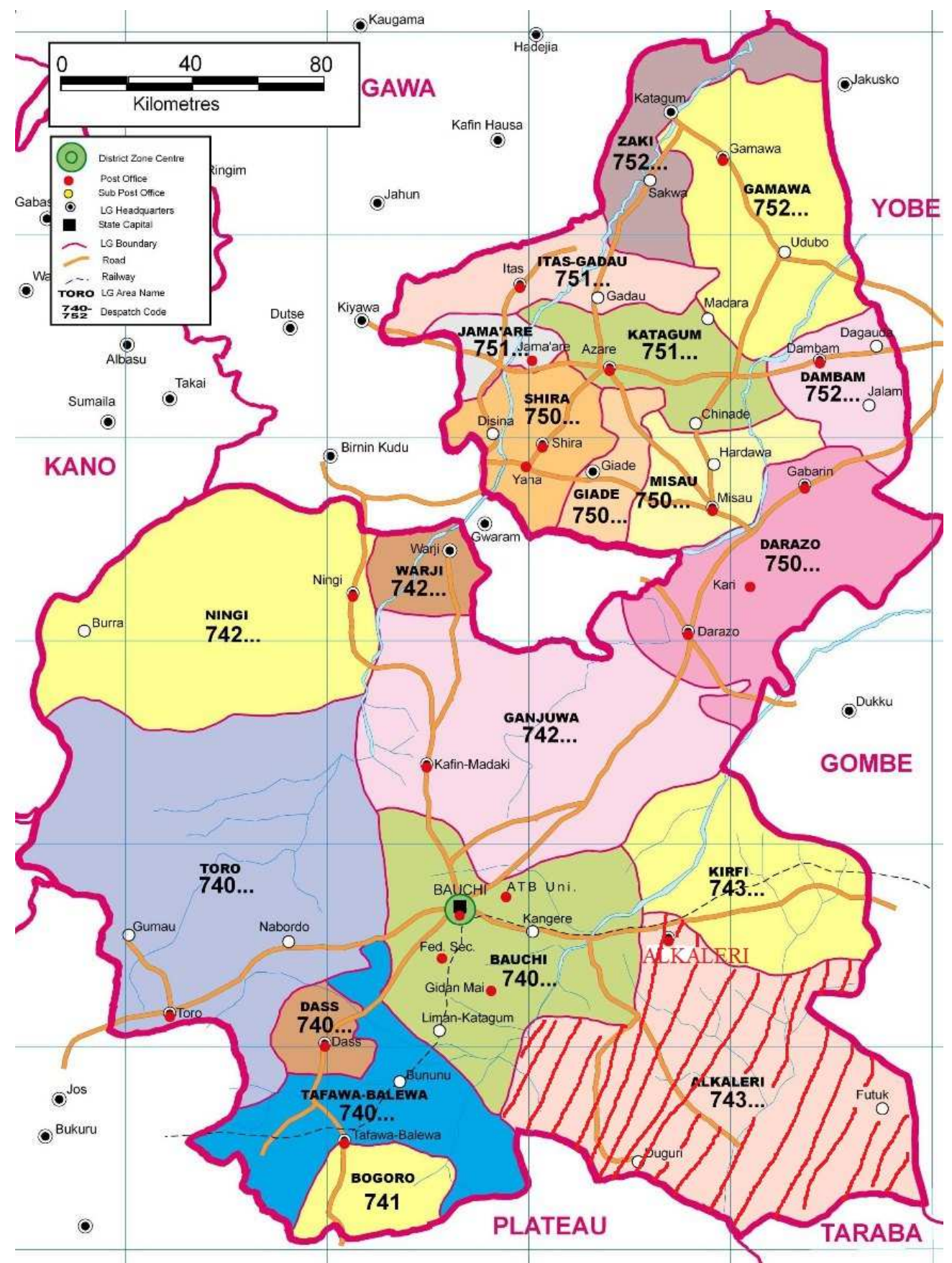

Figure 1. Location map of Alkaleri Kaolin Deposit.

Samples were collected from Alkaleri in Bauchi state, Nigeria. Alkaleri lies between Latitude $10^{\circ} 16^{\prime}$ and Longitude $10^{\circ} 20^{\prime}$ North Eastern part of Nigeria. The Map of the sample location is shown in Figure 1. The Samples were collected manually into polythene bags at the site at depths of $2 \mathrm{~m}$ and $4 \mathrm{~m}$. They were oven-dried at a temperature of $100^{\circ} \mathrm{C}$ followed by homogenisation with a pestle and a wooden mortar. This was done through grinding and turning of the mixed samples in the mortar. Thirty-three composite samples were made from the samples collected at the sites. In order to avoid contamination, samples were kept in a vessel appropriate for the type of irradiation to be performed. Samples requiring short irradiation time ( $<20$ minutes) and low to moderate flux density were each packed and sealed in $7 \mathrm{~cm}^{3}$ rabbit capsules. For elements of long activation period, samples were wrapped in polyethylene films and packed in a stack inside the $7 \mathrm{~cm}^{3}$ rabbit capsule and sealed for irradiation [13]. 


\subsubsection{Metal Determination Using Neutron Activation Method}

Two analytical procedures of Instrumental Neutron Activation Analysis (INAA) with Near Infra-Red (NIRR-1) carried out at Energy Research Centre of Ahmadu Bello University Zaria were used. The first involved a short irradiation regime of $<20$ minutes, followed by gamma ray measurements after appropriate decay period and suitable for identification and quantifying the following elements Al, Dy, $\mathrm{Mn}, \mathrm{Na}, \mathrm{Ti}, \mathrm{Zn}, \mathrm{Ca}$. The second procedure involved a long irradiation regime of $6-7$ hours for identifying and quantifying the following elements; $\mathrm{Ba}, \mathrm{Ce}, \mathrm{Co}, \mathrm{Cr}, \mathrm{Cs}, \mathrm{Eu}$, Fe, Hf, La, Lu, Rb, Sm, Ta, Tb, Th, U, Yb.

\subsubsection{Measurements in Neutron Activation Analysis}

The packaged samples were placed near the core of the nuclear research reactor where the neutrons emitted by the reactor interacted with the nuclei of the atoms of the elements causing them to become radioactive. The short regime capsules were sent in for irradiation in turn in an outer irradiation channel B4 where the neutron section or flux is of low to moderate flux densities. The long irradiation regime rabbit capsules were placed in the inner irradiation channels (A1, B1, B2, B3) to take advantage of the maximum value of thermal neutron flux in the inner channels and were irradiated for six (6) hours. The stability of the neutron flux throughout the period was checked by monitoring the neutron flux reading of a fusion chamber connected to a micro-computer control system. Radioactivity measurements of the induced radionuclide was performed by a gamma-ray spectrometry.

\subsection{Standard for INAA Determination}

Varying the accuracy and quantification result of the INAA procedure is as important as with any viable analytical technique, while in theory it is feasible to calculate target atoms mathematically, it is generally not acceptable since there can be significant uncertainties in value available for various nuclear parameters. Equally important is the fact that the neutron energy spectrum and flux densities of the reactor are not always constant and can vary during different irradiation periods. For these reasons, standard certified reference material of the Chinese geo-chemical rock standard GSD -11 and GSR -5 were used as standard for analytical quality control to validate the procedure of elements of interest in the sample [13].

\section{Results}

Table 1. Metals and their corresponding oxide composition in Alheri Kaolin.

\begin{tabular}{lllll}
\hline S/N & METAL & CONTENT & $\begin{array}{l}\text { CORRESPONDING } \\
\text { OXIDES }\end{array}$ & CONTENT \\
\hline 1 & $\mathrm{Al}$ & $17.388 \%$ & $\mathrm{Al}_{2} \mathrm{O}_{3}$ & $32.9 \%$ \\
2 & $\mathrm{Fe}$ & $11.07 \mathrm{ppm}$ & $\mathrm{Fe}_{2} \mathrm{O}_{3}$ & $1.1 \mathrm{X} 10^{-3} \%$ \\
3 & $\mathrm{~K}$ & $0.44 \%$ & $\mathrm{~K}_{2} \mathrm{O}$ & $0.53 \%$ \\
4 & $\mathrm{Na}$ & $134.7 \mathrm{ppm}$ & $\mathrm{Na}_{2} \mathrm{O}$ & $0.018 \%$ \\
5 & $\mathrm{Ti}$ & $4.61 \mathrm{ppm}$ & $\mathrm{TiO}_{2}$ & $7.9 \times 10^{-4} \%$ \\
6 & $\mathrm{Ba}$ & $42.1 \mathrm{ppm}$ & $\mathrm{BaO}$ & $4.2 \times 10^{-3} \%$ \\
\hline
\end{tabular}

Table 2. Metal oxides specifications of kaolin for use in Paper Industries.

\begin{tabular}{llll}
\hline \multirow{2}{*}{$\mathbf{S} / \mathbf{N}$} & \multirow{2}{*}{ OXIDES } & \multicolumn{3}{l}{ SPECIFICATIONS } \\
\cline { 3 - 4 } & $\mathrm{Al}_{2} \mathrm{O}_{3}$ & 35.0 & MAX \\
\hline 1 & $\mathrm{Fe}_{2} \mathrm{O}_{3}$ & - & 4.0 \\
2 & & & \\
\hline
\end{tabular}

(www.madeinchina.com, 2007)

Table 3. Metal oxides specifications of kaolin for use in Ceramics Industries.

\begin{tabular}{llll}
\hline \multirow{2}{*}{ S/N } & \multirow{2}{*}{ OXIDES } & \multicolumn{2}{l}{ SPECIFICATIONS } \\
\cline { 3 - 4 } & & MIN & MAX \\
\hline 1 & $\mathrm{Al}_{2} \mathrm{O}_{3}$ & 37.47 & \\
2 & $\mathrm{Fe}_{2} \mathrm{O}_{3}$ & - & 0.74 \\
3 & $\mathrm{~K}_{2} \mathrm{O}$ & - & 0.89 \\
4 & $\mathrm{Na}_{2} \mathrm{O}$ & - & 0.16 \\
5 & $\mathrm{TiO}_{2}$ & - & 0.06 \\
\hline
\end{tabular}

(Hansen, 2003)

Table 4. Metal oxides specifications of kaolin for use in Rubber and Plastic Industries.

\begin{tabular}{llll}
\hline \multirow{2}{*}{$\mathbf{S} / \mathbf{N}$} & \multirow{2}{*}{ OXIDES } & \multicolumn{2}{c}{ SPECIFICATIONS } \\
\cline { 3 - 4 } & & MIN & MAX \\
\hline 1 & $\mathrm{Al}_{2} \mathrm{O}_{3}$ & 32.0 & 45.0 \\
2 & $\mathrm{Fe}_{2} \mathrm{O}_{3}$ & 0.35 & 0.5 \\
3 & $\mathrm{~K}_{2} \mathrm{O}$ & 0.08 & 0.1 \\
4 & $\mathrm{Na}_{2} \mathrm{O}$ & 0.5 & 1.5 \\
5 & $\mathrm{TiO}_{2}$ & 0.05 & 1.0 \\
\hline
\end{tabular}

(www.tradekey.com/selloffer-view/id/446920.htm)

Table 5. Metal oxides specifications of kaolin for use in Pharmaceutics and Cosmetics.

\begin{tabular}{llll}
\hline \multirow{2}{*}{ S/N } & \multirow{2}{*}{ OXIDES } & \multicolumn{2}{l}{ SPECIFICATIONS } \\
\cline { 3 - 4 } & & MIN & MAX \\
\hline 1 & $\mathrm{Al}_{2} \mathrm{O}_{3}$ & 38.0 & \\
2 & $\mathrm{Fe}_{2} \mathrm{O}_{3}$ & & 0.7 \\
3 & $\mathrm{TiO}_{2}$ & & 0.05 \\
\hline
\end{tabular}

(www.mp-solutionsinc.com/database, 2007)

Table 6. Metal oxides specifications of kaolin for use in Porcelain Products.

\begin{tabular}{llll}
\hline \multirow{2}{*}{ S/N } & OXIDES & \multicolumn{3}{l}{ SPECIFICATIONS } \\
\cline { 3 - 4 } & & MIN & MAX \\
\hline 1 & $\mathrm{Al}_{2} \mathrm{O}_{3}$ & 35.0 & - \\
2 & $\mathrm{Fe}_{2} \mathrm{O}_{3}$ & - & 0.8 \\
3 & $\mathrm{TiO}_{2}$ & - & 0.2 \\
\hline
\end{tabular}

(www.alibaba.com, 2007)

Table 7. Metal oxides specifications of kaolin for use in Glaze production.

\begin{tabular}{llll}
\hline \multirow{2}{*}{ S/N } & \multirow{2}{*}{ OXIDES } & \multicolumn{3}{l}{ SPECIFICATIONS } \\
\cline { 3 - 4 } & & MIN & MAX \\
\hline 1 & $\mathrm{Al}_{2} \mathrm{O}_{3}$ & 35.0 & 44.9 \\
2 & $\mathrm{Fe}_{2} \mathrm{O}_{3}$ & - & 0.7 \\
3 & $\mathrm{~K}_{2} \mathrm{O}$ & - & 1.1 \\
4 & $\mathrm{Na}_{2} \mathrm{O}$ & - & 0.2 \\
5 & $\mathrm{TiO}_{2}$ & - & 0.4 \\
6 & $\mathrm{Ba}$ & - & Insignificant \\
\hline
\end{tabular}

(www.alibaba.com, 2007) 
Table 8. Metal oxides specifications of kaolin for use in Paints production.

\begin{tabular}{lll}
\hline $\mathbf{S} / \mathbf{N}$ & OXIDES & SPECIFICATIONS \\
\hline 1 & $\mathrm{Al}_{2} \mathrm{O}_{3}$ & 37.0 \\
2 & $\mathrm{Fe}_{2} \mathrm{O}_{3}$ & $0.5^{*}$ \\
3 & $\mathrm{~K}_{2} \mathrm{O}$ & $0.04^{*}$ \\
5 & $\mathrm{TiO}_{2}$ & $0.2^{*}$ \\
\hline
\end{tabular}

(www.alibaba.com, 2007), * = maximum

Table 9. Metal oxides specifications of kaolin for use in Tiles.

\begin{tabular}{lll}
\hline $\mathbf{S} / \mathbf{N}$ & OXIDES & SPECIFICATIONS \\
\hline 1 & $\mathrm{Al}_{2} \mathrm{O}_{3}$ & 23.5 \\
2 & $\mathrm{Fe}_{2} \mathrm{O}_{3}$ & $1.1^{*}$ \\
\hline
\end{tabular}

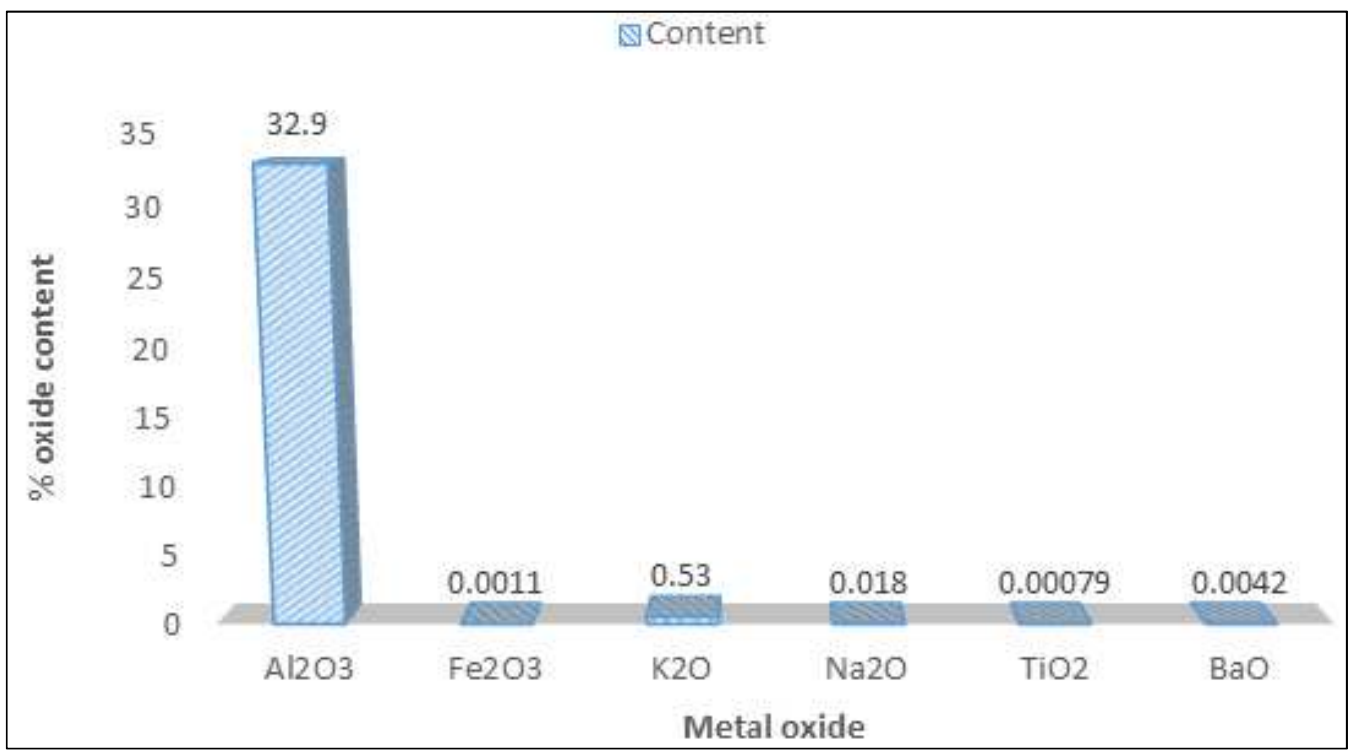

Figure 2. Percentage oxide content of Alheri Kaolin.

\section{Discussion}

The iron content of $\left(1.1 \times 10^{-3} \%\right)$ of Alkaleri kaolin is below the maximum requirement of kaolin for paper production. Thus, it could be used for high quality paper production because the lesser the iron, the better the quality for paper production [14], but the $\mathrm{Al}_{2} \mathrm{O}_{3}$ content $(32.9 \%)$ of the kaolin may reduce its potential use in the paper industry since it is below the minimum specification as shown in Table 2 .

According to Hansen (2003), tolerance value for good quality kaolin clay for the ceramic industry is given in Table 3. The Alkaleri kaolin with the following percentage elemental composition; $\mathrm{Fe}\left(1.1 \times 10^{-3} \%\right), \mathrm{K}_{2} \mathrm{O}(0.53 \%) \mathrm{Na}_{2} \mathrm{O}$ $(0.081 \%)$ and $\mathrm{Ti}\left(4.6 \times 10^{-4} \%\right)$ is within the specification for good kaolin clay for ceramic uses, but the $\mathrm{Al}_{2} \mathrm{O}_{3}$ content $(32.9 \%)$ is $2.1 \%$ less than the minimum requirement of $35 \%$ for ceramic. The Ba content $\left(1.2 \times 10^{-3} \%\right)$ could pose a health threat in its selective use in the ceramic industry because $\mathrm{Ba}$ could be leached from ceramic materials and when ingested is carcinogenic [15] and could cause stomach irritation, high blood pressure, brain, liver and heart damage. This implies that the $\mathrm{Al}_{2} \mathrm{O}_{3}$ content which is below the minimum requirement and the $\mathrm{Ba}$ content could depreciate the quality for the ceramic industry.

The industrial chemical specification for kaolin clays used as fillers in rubber and plastic industry given by $\mathrm{Ou}(2007)$ is presented in the Table 4 . The $\mathrm{Al}_{2} \mathrm{O}_{3}$ content $(32.9 \%)$, Fe $\left(1.1 \times 10^{-3} \%\right), \quad \mathrm{Na}_{2} \mathrm{O}\left(1.81 \times 10^{-4} \%\right), \quad \mathrm{TiO}_{2}\left(7.7 \times 10^{-4} \%\right)$ are within the specified values for good quality kaolin filler for rubber use. The Mn $\left(1.58 \times 10^{-2} \%\right)$ though low may affect the vulcanization process, as $\mathrm{Mn}$ is expected to be absent in kaolin raw materials for this use. The $\mathrm{K}_{2} \mathrm{O}$ and $\mathrm{Mn}$ could reduce the quality but if chemically treated to remove its $\mathrm{K}_{2} \mathrm{O}$ and $\mathrm{Mn}$ content, it could be a good quality filler.

The chemical specification in Table 5, implies that the $\mathrm{Al}_{2} \mathrm{O}_{3}$ content $(32.9 \%)$ of Alheri is below the minimum specified range and hence decreased its quality for use in Pharmaceutical and Cosmetic industries but the $\mathrm{Fe}\left(1.1 \times 10^{-3} \%\right)$ and $\mathrm{TiO}_{2}$ $\left(7.7 \times 10^{-4} \%\right)$ are within the specified values.

Porcelain material require kaolinite clays with low ironoxide content to encourage packing and cohesion (binding effect) of the large particle size and minimum titanium content to enhance translucency [15]. This implies that kaolin clay material used for high quality porcelain products should have low iron and titanium-oxide contents. The $\mathrm{Fe}(0.0011 \%)$ and $\mathrm{Ti}_{2} \mathrm{O}(0.00046 \%)$ values are within the specification 
Table 6. However, the $\mathrm{Al}_{2} \mathrm{O}_{3}$ content of $32.9 \%$ is below the minimum requirement, hence could reduce the its quality for this use.

Hansen stated that good quality glaze requires kaolin rich in alumina, i.e. the more the alumina the higher their quality and usefulness for glaze manufacture [15]. The general specification for kaolin clay material use for glaze is given in Table 7. The $\mathrm{Al}_{2} \mathrm{O}_{3}$ content of $(32.9 \%)$ is slightly below the specification but the $\mathrm{Fe}\left(1.1 \times 10^{-3} \%\right), \mathrm{K}_{2} \mathrm{O}(0.53 \%), \mathrm{Na}_{2} \mathrm{O}$ $(0.081 \%), \mathrm{TiO}_{2}\left(4.7 \times 10^{-4} \%\right)$ are all within specification given, and maybe considered good for glaze production.

The specification of kaolin for the paint industry is given in Table 8 . The $\mathrm{Al}_{2} \mathrm{O}_{3}$ content of $32.9 \%$ is below the specified value but $\mathrm{Fe}\left(1.1 \times 10^{-3} \%\right), \mathrm{TiO}_{2}\left(4.7 \times 10^{-4} \%\right)$ are within specification and could enhanced the quality of Alheri kaolin for this use but the lower $\mathrm{Al}_{2} \mathrm{O}_{3}$ content may slightly depreciates its quality for use in paint industry.

The chemical specification for used for walls and floor is given in Table 9. The $\mathrm{Fe}\left(1.1 \times 10^{-3} \%\right)$ is within the specification but the $\mathrm{Al}_{2} \mathrm{O}_{3} \quad(32.9 \%)$ is above the specification. Chemical treatment of the Alheri kaolin to reduce it aluminum content could enhance its utility in this regard.

The kaolin indicated a phosphate content of 5.95ppm. The combination of sulphate content of $4.71 \%$ enhances it absorbing abilities. Hence, their increased value for cosmetics pharmaceutics and other scientific use. It also improves the quality for alum production, since sulphate in alum increases its regimenting power. The Nitrate content is found to be $18 \mathrm{ppm}$. This enhanced the quality of the kaolin for drugs in the treatment of granite poisoning. The chloride content is very low and found to be $0.3 \mathrm{ppm}$. The $\mathrm{pH}$ of the kaolin sample is found to be 4.3 . This makes it necessary to increase the value to between 5 and 7 so as to make it suitable for most industrial purposes, e.g. rubber production.

\section{Conclusion}

Elemental analysis of the Alheri kaolin has revealed that it has an enormous potential for use as raw material in various industrial applications ranging from pharmaceutical and cosmetic industries, tiles, ceramics, porcelain, paints, rubber and plastics industries as well as paper industries.

The purity and quality of Alkaleri kaolin for any use depends on the alien substances present. While one alien substance can raise the quality of the kaolin for a particular purpose, the same substance could decrease the quality for another purpose. Thus, Chemical treatment of the clay prior to use for specific industrial applications is recommended. It is hoped that the findings of this research would be of immense help to Industrialists and academic researchers globally.

\section{References}

[1] Ground report (2016). What makes kaolin clay different from kaolinite clay. Retrieved 07 August, 2017 from https://www.groundreport.com/makes-kaolin-clay-differentkaolinite-clay

[2] Newman, A., 1987. Chemistry of Clay and Clay Minerals, Min. Soc. Mon., London, 6, 480.

[3] Konta, J., 1980. Properties of ceramic raw materials. Ceramic monographs. Handbook of ceramics, Schmid -Freiburg, 1-32.

[4] Murray, H., 2000. Traditional and new applications for kaolin, smectite, and palygorskite: a general overview, Applied Clay Science, Vol. 17, No. 5-6, 207-221.

[5] Cravero, F., Gonzalez, I., Galan, E., and Dominguez, E., 1997. Geology, mineralogy, origin and possible applications of some Argentinian kaolins in the Neuquen basin. Applied Clay Science, Vol. 12, No. 1-2, 27-42.

[6] Prasad, M., Reid K. and Murray H., 1991. Kaolin: processing, properties and applications. Applied Clay Science, Vol. 6, No. 2, 87-119.

[7] Murray, H., 1991. Overview-clay mineral applications. Applied Clay Science, Vol. 5, No. 5-6, 379-395.

[8] Burst, J., 1991. The application of clay minerals in ceramics. Applied Clay Science, Vol. 5, No. 5-6, 421-443.

[9] Murray, H., and Kogel, J., 2005. Engineered clay products for the paper industry, Applied Clay Science, Vol. 29, No. 3-4, 199-206.

[10] Velho J. and Gomes, C., 1991. Characterization of Portuguese kaolins for the paper industry: beneficiation through new delamination techniques. Applied Clay Science, Vol. 6, No. 2, 155-170.

[11] Bundy, W., and Ishley J., 1991. Kaolin in paper filling and coating. Applied Clay Science, Vol. 5, No. 5-6, 397-420.

[12] Schupp, J. R., Fallahi, E., and Chun, I.-. J., 2004. Effect of Particle Film on Fruit Sunburn, Maturity and Quality of "Fuji" and "Honeycrisp" Apples. Acta Hort. (ISHS) Vol. 636, 551556.

[13] Jonah, S. A., Umar, I. M., Oladipo, M. O. A., Balogun, G. I. and Adeyomo, D. J. (2006): Standardization of NIRR-1 Irradiation and Counting Facilities for Instrumental Activation Analysis. J. Applied Radiation and Isotopes, 64: $818-822$.

[14] Johnstone, S. J., Johnstone, M. G. (1961). Minerals for the Chemical and Allied Industries. In: Ahmed, K. S. (1986). Development of Phospate-Bonded Fire Clay Refractory Castables. Unpublish M. Sc. Thesis, Department of Chemical Engineering, Ahmadu Bello University, Zaria.

[15] Hansen, T. (2003). Titanium oxide, Titania. Ceramic materials Data Base. Retrieved 10 August, 2017 from http://ceramicmaterials.com/com/cermat/html 